\title{
Reframing labour market mobility in global finance: Chinese elites in London's financial district
}

Sarah Hall

School of Geography

University of Nottingham

Nottingham NG7 2RD

Sarah.hall@nottingham.ac.uk

Paper accepted in Urban Geography on 30 April 2018.

6427 words excluding references

\begin{abstract}
In this paper, I use the case of elite Chinese financial mobility to London's financial district to argue that comparatively neglected forms of elite financial migration from beyond the Global North provide important insights into the changing geographical form, and labour market practices within, leading international financial centres. By reporting on original empirical research, two main findings emerge. First, Chinese financial mobility to London has a distinctive geographical footprint in terms of both financial services activity and residential choices. Second, the rationale behind elite Chinese financial mobility to London cannot be fully explained by existing work on highly skilled migration and expatriation that emphasises the economic imperatives driving mobility. In response, I argue that work on elite mobility requires a fuller engagement with wider debates in economic geography that examine the interdependencies and inter-relationships between states and markets. These findings raise important questions surrounding the durability of Chinese finance in London, its relationship to global finance in London more generally, and wider understandings of elite financial labour markets.
\end{abstract}

\section{Keywords}

mobility, expatriation, Chinese banking and finance, RMB internationalisation, City of London, elites 


\section{Reframing labour market mobility in global finance: Chinese elites in London's financial district}

\section{Introduction}

The international mobility of financial elites has attracted growing academic, popular and political attention in recent years (see, for example, The Financial Times, 2016). Research in this area emphasises how such mobilities shape the flows of knowledge and expertise through which international financial centres (IFCs) are reproduced (Beaverstock, 1996; Beaverstock and Hall, 2012; Sassen, 2000; Thrift 1994). This work builds on, and contributes to, a wider literature on elite, or what Kunz (2016) terms 'privileged mobilities' (see also Sklair, 2001; Smith, 2001). However, the geographical focus of this work remains limited. Studies typically focus on flows of migrants either between IFCs in Europe and North America (Beaverstock, 2005; Ryan and Mulholland, 2014) or on the mobility of individuals from the Global North to rapidly growing economies, often in Asia and the Middle East (Beaverstock, 2002). As a result, little is known about what happens to theoretical understandings of the rationale behind, and implications of, international mobility when different geographies of mobility are in play (although for exceptions see Knowles 2017; Moore, 2016).

In response, and inspired by calls to take the urban dimensions of mobility seriously (Smith, 2001), this paper reports on original research conducted into flows of Chinese financiers from mainland China to London. This empirical focus is significant for two reasons. First, figures show that Chinese born nationals now make up the 
largest source of migrants to the UK (Dominiczak, 2013) and yet understandings of Chinese migration to the UK remain largely rooted in earlier waves of immigration that were characterised by migrants working in lower paid service sector jobs, particularly the restaurant and food trade (Knowles, 2017, Pieke, 2007). Second, demand for elite Chinese financial labour in London has grown significantly since 2012, following London's development as a leading western centre for the internationalisation of China's currency, the renminbi (RMB) (Hall, 2017a; Hall, 2017b; Töpfer and Hall, 2017).

By reporting on findings relating to the motivations, experiences and future planned trajectories of Chinese financiers in London, two main findings emerge. First, Chinese financial migration into London has a distinctive geographical footprint in terms of both financial services activity and the residential choices of Chinese. This points to the emerging, ways in which Chinese finance is beginning to shape London's wider economy. This is not limited to the financial services activity at the heart of RMB internationalisation but, also extends to Chinese investment in London real estate and the significance of Chinese retail spending in the development of luxury consumption practices in London (on which see Atkinson et al, 2017 and JLL, 2015 respectively).

Second, the rationale behind elite Chinese financial mobility in London does not sit neatly within existing understandings of elite mobility and expatriation that emphasise the economic rationales underpinning such mobility, particularly at the firm level (see Beaverstock, 2004 for example). Whilst my analysis shows that for 
some financiers, their motivations for working in London were underpinned by economic motives that dominate existing theoretical explanations of elite migration, political motives also need to be more fully theorised than has been hitherto the case. In this sense, the work and mobility of Chinese financial elites was closely tied into the Chinese state project aimed at having strategically important IFCs such as London tied into the RMB internationalisation process (see also Töpfer and Hall, 2017). This finding suggests that work on elite migration could usefully draw on wider debates in economic geography that seek to understand the interdependencies and inter-relationship between states and markets (see O'Neill, 2008 for example) as the Chinese and UK state facilitate Chinese elite migration to London and in turn this migration supports wider state policies relating to both RMB internationalisation and the wider competitiveness of London as an IFC. Taken together, these findings raise important questions concerning the future trajectory of Chinese elite migration to London as well as broader points concerning London's future development as an IFC following the referendum vote to leave the EU by the UK in June 2016 (Hall and Wójick, 2018).

I develop these arguments over four sections. Next I locate the mobility and expatriation of Chinese financiers within the wider literatures on elite migration and expatriation in general, and Chinese mobility into London in particular. I then reveal the geographies of Chinese finance and financiers in London, revealing how Chinese financial elites, and the financial institutions they work for, are concentrated in the historic centre of London's financial district and inner London boroughs with important consequences for the relationship between Chinese financial elites and 
elite labour markets more generally in London. In the next substantive section, I explore the different routes by which these geographies have been created through Chinese elite migration and expatriation into London. Here, I examine how Chinese financial elites in London are typically at an earlier career stage than elites from Europe and North America that have been more widely studied. This career stage reveals close links between educational background and elite Chinese mobility in ways that trouble assumptions of a relatively seamless transition from selected higher education institutions and elite financial labour markets. I conclude by reflecting on the implications of these findings for understandings of labour market mobility in global finance in general, and the reproduction of London as an international financial centre in particular.

Mobility and international financial centres: the case of elite Chinese urban economies

My analysis of the mobility of Chinese financiers into London takes as its starting point the growing academic interest in highly skilled labour between nation states over the least twenty-five years (see for example Iredale, 2001; Koser and Salt, 1997). Much of the early research in this area focused on the mobility of individuals with higher educational qualifications within the transnational corporations they worked for (Findlay et al 1996). The geographical focus of this work on mobility was dominated by migration from and between global cities within advanced economies (Sassen, 2000). For example, work on inter-company transferees, particularly in its earliest phases, emphasised the ways in which individuals from Europe and North 
America especially were sent by their employers as expatriates to newly opened offices in rapidly growing economies in order to ensure that similar standards of service were maintained in newly opened offices as compared to the firm's headquarters (Beaverstock, 2004).

Building on this early work, research increasingly began to interrogate who counted as a highly skilled migrant by studying more closely the types of assignments being undertaken by migrants, and the geographies associated with these (Findlay and Cranston, 2015). Reflecting this questioning of the term 'highly skilled', as well as a desire to acknowledge the privileged economic and political position of the Chinese nationals involved in this research, I use the term elite mobility rather than highly skilled migrant in my analysis (see Savage and Williams, 2008 for a wider discussion of the importance of studying elites within the contemporary global economy). Research also began to move beyond mobility driven through inter-firm transfers to examine the mobility of the self-employed and entrepreneurs (Saxenian, 2006; Ley, 2010). This change in focus brought with it a greater attention to understanding the rationale for mobility moving beyond a focus on disseminating best practice from the headquarters of transnational corporations typically through flows of migrants from the Global North. Rather, research became increasingly concerned with understanding the ways in which migration can be used to foster economic development and innovation within mature economies (Faulconbridge et al, 2009), often raising concerns about a potential loss of 'talent' in their home economies (Saxenian, 2006; Florida, 2007). 
However, in the case of financial services, the geographical imaginations of work on elite migration have not widely embraced the more heterodox geographies of this work on migration and expatriation from beyond the Global North. Typically, research has focused on the heartlands of global finance through research into the nature of financial centres in Western Europe and North America, or on the circulation of elites from these leading financial centres to other spaces of global finance through processes such as expatriation (Beaverstock, 2002, 2005). This builds on a wider understanding in academic and policy circles that has frequently identified a ready supply of graduate labour as a key factor in explaining the competitiveness of leading financial centres (Beaverstock and Hall, 2012; Z/Yen, 2016). However, as Robinson $(2002,2005)$ has argued, much of this work is characterised by a distinctive geographical focus on the mobility of elites from the Global North to other parts of the world. As a result, much less attention has been paid to financial elites beyond Western Europe and North America, their mobility patterns and working practices (although see Bassens et al, 2011, 2010; Lai, 2012; Krijnen et al, 2017 and Kleibert and Kippers, 2016).

\section{Reframing elite mobility between financial centres}

The case of Chinese migration into London, therefore, raises important questions about how well our existing understandings of the motivations, experiences and trajectories of migration within the financial services sector can explain elite Chinese mobility into London and its role in IFC formation and reproduction. Addressing these concerns is also important in terms of updating understandings of Chinese 
migration to London, and the UK more generally, that remain largely rooted in more historic migration flows of Chinese nationals working in lower paid service and hospitality sectors. In this respect, it is important to locate the forms of mobility studied in this paper within the wider transformation of Chinese migration from a process that was only permitted from Hong Kong and other overseas Chinese territories, to one open to a far wider segment of the Chinese population, particularly the rapidly growing Chinese middle class and young people undertaking mobility for studying (Pieke, 2007).

After the Second World War, the People's Republic of China (PRC) effectively banned all official emigration until the 1960s (Pieke, 2007). As a result, there were only modest international migration flows from Hong Kong and Taiwan to the UK, reflecting their unique political status as overseas territories. In contrast to the Chinese migrants who form the basis of this paper, in terms of occupation, this migration stream to the UK was characterised by individuals working in relatively low paid, service sector jobs, particularly in the catering sector (see Findlay and Li, 1998). This pattern of migration changed from the 1980 s onwards as the PRC began to relax the regulations surrounding migration. Following this, migration became an option for Chinese citizens from mainland China who could demonstrate they could legitimately enter a foreign country (Xiang, 2003). As a result, two migration flows from mainland China to the UK can be identified from the 1980 s onwards as part of what Pieke (2007) terms the 'new Chinese migration order'. 
First, Chinese elite migration grew significantly from the 1990s onwards, reflecting the wider opening up of the Chinese economy associated with domestic economic reform. As a result, an increasingly entrepreneurial elite Chinese middle class emerged in China, for whom international migration represented a significant economic and cultural opportunity (Tomba, 2004). Work on the resulting diaspora of skilled Chinese migrants has cautioned against simply inserting this group of migrants into existing frameworks for understanding elite migration. For example, Saxenian's (2006) seminal analysis of the role of migration from China (amongst other countries) in the labour markets of Silicon Valley recasts this migratory flow away from understandings of an engineering brain drain from China and instead develops understandings of brain circulation as Chinese migrants return to China, and in so doing shape economic growth in China and Silicon Valley (see also Ong, 1999).

Second, building on a more established history of migration from the 1960s onwards from Hong Kong to the UK for educational purposes, significant research attention has been paid to the growth of education related migration from mainland China from the 1990s onwards (Waters, 2006). Again, political economic changes within China are important for understanding the growth and transformation of this form of migration. The rise of a Chinese middle class alongside Chinese entrepreneurs has increased the number of Chinese households who are able to afford foreign education for their children. This has expanded beyond a preference for postgraduate education, largely in North America in the 1990s (Pieke, 2007) to include undergraduate degrees, compulsory schooling and short-term English 
language courses in a more diverse range of geographical locations, particularly in the UK and western Europe (Bohm et al, 2004).

Taken together, this work is important in revealing the particular political, economic and cultural contexts shaping contemporary forms of elite Chinese migration. However, less attention has been paid to the migration of Chinese born nationals into financial and related professional services, and it is this that I address in the rest of this paper.

\section{Methods}

The paper draws on two main strands of research. The first seeks to quantify and document the spatiality of elite Chinese financial migration in London. This seemingly straightforward task becomes more challenging given the acknowledged difficulty of obtaining accurate data on elite migration to the UK more generally, particularly in terms of the nationality of migrants (Findlay and Gould 1989). As a result, it is difficult to use official data sources to disaggregate the number of Chinese migrants working in London by sector. For example, because the UK census is only conducted every 10 years with the last one being held in 2011, the recent impact of RMB internationalisation on Chinese migration to the UK from 2012 onwards is not picked up in census data. In order to overcome the temporal limitations of other forms of migration data, my research draws on an analysis of new national insurance registrations by adult overseas nationals entering the UK by year of registration. This data is provided by the Department for Work and Pensions 
and has the advantage of being updated annually. A National Insurance (NI) number is needed to pay tax in the UK and hence captures economically active migrants and can be located geographically within London. However, it is not disaggregated by sector so inferences have to be made based on the location of migrants in order to estimate the sectors in which they work.

Therefore, in order to better understand the motivations behind the migration patterns shown in quantitative data, the second methodology used in my research are semi-structured interviews with Chinese migrants working in London's financial district. This method also posed important methodological issues including securing access and the situated nature of the knowledge produced, both of which have been well documented in relation to elite corporate interview more generally (see Schoenberger, 1991, 1992, and McDowell, 1992 in general and McDowell 1998 on the case of financial elites in particular). I used several strategies to access individuals in order to undertake thirty interviews between September 2014 and June 2015 with Chinese financiers working in a range of RMB denominated financial markets in London. Conventional ways of accessing financial elites do not work in the case of Chinese migrants working in financial services in London. For example, typically the more senior employees within financial organisations can be accessed via their firm's corporate website. However, the overwhelming majority of the migrants I interviewed were at an early career stage (twenty five out of thirty) and hence did not appear on lists of companies managing boards. Meanwhile, the websites of Chinese financial institutions operating in London's financial district, 
particularly the state owned commercial banks, remain rudimentary in nature and do not contain staff names and contact details.

In response, I used the business orientated social network LinkedIn.com as my primary way of accessing initial research participants. Through my own LinkedIn account, I searched for individuals working in the state owned commercial Chinese banks operating in London, setting out the details of my research and asking if they would be prepared to meet for an interview. Given the unsolicited nature of my enquiry, I was expecting a very low success rate. However, to my surprise this proved very productive and I secured interviews with individuals working at different levels within these banks. During the interview, I asked why they had been keen to participate. The value placed on the cultural capital associated with education amongst Chinese migrants (Waters, 2005) and my own position as a university professor at a larger UK higher education institutions with operations in China emerged as key factors in them agreeing to the interview (this echoes McDowell's [1998] discussion of how her own career trajectory facilitated research entry into London in the late 1990s). It also became apparent that as a female researcher, my interviewees positioned me as an outsider, as they themselves felt, within London's financial district. So, whilst, they understood my position as being different from the dominant masculine subjectivities of the City, they felt they shared with me a sense of being 'other' through their position within a relatively small elite migrant group, and this was frequently used in their responses to my questions. This experience builds on the wider feminist literature on the intersectional positionality of 
interviewers, and female interviewers as legitimacy was conferred on me by my respondents because of my job in education whilst simultaneously being seen as non-threatening and relatively powerless (see Pratt, 1993 and England, 1994). Comments such as the following were typical in this respect

\footnotetext{
"You'll understand the difficulties of getting on in a labour market like this when you don't quite fit in - I don't always feel like employers know how to handle my difference - different background, different skills and different aspirations"
}

(Associate, European investment bank, London June 2015)

From these initial contacts, I used a process of snowballing to access other Chinese migrants working in a range of financial institutions that were both Chinese and internationally owned. In so doing, I was made aware of several online and 'real world' social networks for Chinese financiers in London that were either education based (e.g. alumni groups from Masters of Finance degrees at the London Business School) or aimed at supporting Chinese migrants in their career development (e.g. The Association of Chinese Financial Professionals in the UK). These organizations were important in terms of recruiting research participants and reflected the demography of Chinese born financiers working in London with most interview respondents aged under thirty-five. Interviews lasted between thirty minutes and two and a half hours, were conducted in English and were recorded and transcribed 
for subsequent analysis within a grounded theory framework. Details of my interviewees are provided in Table 1.

[Table 1 here]

\section{Placing elite Chinese financial migration in London}

Figures from the Office for National Statistics point to a small but rapid growth of Chinese migration to the UK, and Chinese migrants working in financial services in London in particular. For example, the proportion of Chinese migrants working in all sectors across the UK remains small, estimated officially to be $0.72 \%$ of the population of England $(379,503)$. Within this, London has the largest number of Chinese migrants $(124,250$ or $1.52 \%$ of the population, although estimates of undocumented Chinese migrants suggest the figure is closer to 300,000 (Knowles, 2015). Indeed, in 2014, more migrants arrived in the UK from China than from any other country (more than 40,000), and yet they remain one of the least studied migrant groups (Knowles, 2015). Further corroborating this upward trend in Chinese migration to the UK, reports from the executive search sector point to the significant increase in the number of mandarin speakers working in and demanded by London's financial services sector (Mandarin here being significant as it has become increasingly important relative to Cantonese that typified earlier waves of Chinese migration from Hong Kong) (Astbury Marsden, 2014). 
New national insurance registrations allow us to be more specific in terms of charting the growth of Chinese migrants working in London from 2011-12 onwards increasing from 2830 new NI registrations in 2011-12 to 4404 registrations in 201516, an increase of twenty-two per cent (see Figure 1). The timing of this increase fits with London's growing role in RMB internationalisation from 2011 onwards and it is therefore likely that employment in financial and related professional services accounts for at least part of this increase. There is also a geography to $\mathrm{NI}$ registrations of Chinese migrants working in London. As Figure 1 shows, the boroughs showing the largest percentage increase in annual NI registrations for Chinese migrants between 2002-3 and 2015-16 are Camden (438\%), Westminster (406\%), Kensington and Chelsea (332\%), Hammersmith and Fulham (246\%) and the City of London (220\%). These boroughs are typified by their clustering of young urban professionals (Thrift and Leyshon 1992), echoing the age demographic of elite Chinese financiers working in London as well as the global super rich (Atkinson et al 2017). The significant increases in the City of London and Tower Hamlets (126\%) are particularly important for the purposes of the arguments in this paper since these are the boroughs associated with financial services activity and therefore provide an indication that these migrants are working in financial and related professional services.

[Figure 1 here] 
In addition to focusing on individual migrants, the impact of Chinese elite mobility to London working in financial services on London's urban form is also revealed by focusing on the location of Chinese financial firms operating in London. Previous research has clearly documented how waves of internationalisation have shaped both the working practices and associated urban form of London's financial district. This process is characterised by the expansion of international financial service firms from the historic centre of London's financial district close to the Bank of England (Pryke, 1991) eastwards to Canary Wharf (Daniels and Bobe, 1992), northwards and westwards in the case of hedge funds, asset managers and private wealth managers (Hall, 2017c).

Chinese financial services have not followed this trend of outwards geographical expansion beyond the historic centre of London's financial district. Indeed, figure 2 shows that Chinese financial and related professional services are currently clustered closely around the Bank of England. The case of Chinese state owned commercial banks illustrates the preferences for these financial institutions to locate within the City of London most clearly.

[Figure 2 here] 
In terms of bank internationalisation, the rapid and recent growth of London as a leading offshore RMB centre is reflected in the opening of branches by all four of China's biggest commercial banks in London from 2014 onwards (see table 2). Prior to 2013 , Chinese commercial state owned banks could not open branches in London because, in common with other non-EU financial institutions, Chinese banks could only establish subsidiaries rather than full branches in the UK. This reflected the cautious attitude of financial regulators in London to overseas banks in the fallout from the 2007-8 financial crisis (Ying, 2013). Bank subsidiaries were seen to pose less of a risk to systemic financial stability, because they had higher capital and liquidity requirements. The commitment to allowing Chinese banks in the UK to open branches was formalised in October 2013 at the Fifth UK-China Economic and Financial dialogue held in Beijing between the Chinese Vice Premier Ma Kai and the UK's Chancellor of the Exchequer George Osborne. ${ }^{1}$ The first Chinese bank to be given such a licence was Industrial and Commercial Bank of China, which obtained its full UK banking licence in London at the end of 2014 and has been closely followed by the other big four state owned banks (see table 2). The clustering of these banks around the Bank of England reflects their location in Beijing, where being close to the regulator, in this case the People's Bank of China (PBoC), is seen as being central to the learning of key market developments that will shape their organisational strategy and operations. As one banker observed:

\footnotetext{
${ }^{1}$ Economic and Financial Dialogues have been held between monetary and finance ministers in UK and China since 2008 and typically include announcements concerning significant regulatory changes aimed at developing London's role within $\mathrm{RMB}$ internationalization.
} 


\begin{abstract}
"You can draw a very tight circle around the Bank of England if you join the dots between all the Chinese offices in the City [of London]. And that is very Chinese - to be located as close as possible to the regulator" (Trader, Chinese bank, Chinese national, London, March 2015)
\end{abstract}

[insert table 2 here]

The clustering of Chinese professional service firms around the Bank of England is not limited to financial services. In the case of law, the growth of Chinese law firms has been dominated by mergers and joint operations between multinational law firms seeking to access the Chinese market and offer advice to Chinese clients seeking to invest outside of China, and their Chinese counterparts. For example, Baker \& McKenzie, headquartered in Chicago, has developed a joint operation with the Chinese firm FenXun Partners. This allows Baker \& McKenzie to access lawyers practising Chinese law which can only be undertaken by Chinese law firms. Responding to the growing demand from Chinese firms seeking to invest in the UK, the first wholly owned Chinese law firm was established in London in 2015 (Fortado, 2015). As Figure 2 shows, YangTse Law located close to London's financial district, reflecting the close relationship between financiers and lawyers when advising on investment into the UK. 
Taken together, data on recent Chinese migration to London and the mobility of financial and related professional services firms into London provides an important first step in documenting the hitherto neglected growing significance of Chinese finance in London's financial district. However, in order to understand the rationale behind these urban geographies, in depth qualitative research is needed with Chinese migrants.

Understanding the motivations, experiences and trajectories of elite Chinese migration into London

Chinese finance in London is underpinned by two relatively distinct groups of elite Chinese financiers with different migration motivations, experiences and trajectories: first early career financiers building on their higher education credentials acquired in the UK; and second; financiers working on secondment from mainland China within Chinese commercial banks.

Educational routes into elite Chinese financial labour markets

The first group of elite Chinese financiers working in London's financial district are early career financiers who have stayed to work following completion of 
undergraduate or postgraduate degrees in the UK. As such, this groups builds on the more well studied mobility of Chinese higher education students to the UK (Brooks and Waters, 2011). Indeed, China sent the largest number of overseas non-EU students to UK higher education institutions in 2015-16 (the last year for which data is currently available, HESA, 2017). In common with the historic relationship between educational background and entry into elite financial labour markets (Jones 1998), Chinese financiers strategise carefully about the institution they attended and the degree programme they studied, aiming for Oxford, Cambridge or another research-intensive Russell Group university, with a preference for quantitative based degree subjects, often in economics, mathematics, engineering or business studies. This reflects the ways in which these universities were seen as being able to confer the social and cultural capital needed to secure employment in London's financial district, as the following example demonstrates:

"My parents had made it clear that travelling to the UK was a good idea, particularly as it would allow me to work in finance in London. But I had to go to a top ranked University to get the maximum benefit. So I studied economics at Warwick and every summer, applied for internships in London. I followed this with a Masters degree and hoped to use that and my work experience as a way of getting a finance job" (Associate, European investment bank, London, February 2015) 
However, at another level, the case of Chinese migrants' educational routes into financial services work in London departs from established understandings of the relationship between educational background and financial services work in London that have, historically at least, often pointed to a relatively seamless transition from educational attainment at elite universities to employment in financial services (Augar, 2001). Rather, the experiences of young Chinese migrants reveal the challenges of converting highly valued educational credentials from UK universities into a career in financial services in London because of the continued lack of ethnic diversity within elite financial labour markets (see British Bankers Association, 2015 on the case of banking and Johanson and Vahlne 2009 for a broader discussion of 'otherness' within organisations). Indeed, progressing from university to a graduate level position in financial services, particularly in commercial financial services, was the exception rather than the norm amongst the individuals I interviewed. Different strategies were adopted to overcome this. Some graduates took a first position in retail banking, often in a back-office function in a provincial financial centre in which they had studied such as Birmingham or Edinburgh. For example, one banker reflected that

"After my degree [first class economics degree from Birmingham], I applied to all the usual financial houses for their graduate schemes but received no offers. I think it was partly due to concerns about my English for writing reports. That was upsetting as my dream [of using UK education as a point of entry into financial services in the UK] had gone. So, I ended up taking a 
back-office job in Bank of China in Birmingham. It wasn't really what I wanted to do and wasn't very challenging but after two years I moved to their London operations and then moved from retail into their commercial operations."

(Associate, European asset management, London, March 2015)

Even when Chinese migrants were employed in international banking brands, they were often located in parts of the labour market in which skills stereotypically associated with Chinese migrants were valued. Stereotypes based on ethnicity that assumed that Chinese migrants were quantitative financiers led to them being effectively limited to work in back office analytical roles, particularly if they sought to leave Chinese owned financial institutions and work for American or European firms, as the following banker reflected:

“On paper, I have the perfect CV - a first [class degree] from Oxford and a masters in finance from London Business School. I started working for a Chinese bank but could only get hired here [a European bank] through a personal contact and even then, I'm stuck doing analytical work ... my social networks and interests don't fit so well with the organization and I'm only being sponsored by another Chinese employee. I feel like they know I'm good at numbers but don't really look beyond that"

(Analyst, European investment bank, London, March 2015) 
Despite this separation, Chinese financial migrants were eager to use their experience as a stepping stone onto further mobility, often expressing a desire to gain international experience whilst they essentially waited for China's financial centres to develop in ways in which they could then bring their international experience to bear:

I see London as part of my career but no more than that. I'm getting the experience I need here but will ultimately use that in another financial centre, possibly Singapore or maybe Beijing or Singapore when their financial systems are more mature. There I would be closer to home but still working in an exciting centre.

(Analyst, UK bank, London, March 2015

This discussion reveals how Chinese financiers working in London are typically at a much earlier career stage than many of the financial migrants and expatriates studied in existing work on financial elites (Beaverstock, 2004). As such, their career mobility is much more closely linked to their higher education choices, with their educational decision-making often explicitly linked to their financial career aspirations. However, their experiences of trying to secure employment within London's financial district reveals the challenge of trying to overcome the continued 
lack of ethnic diversity in elite financial labour markets to use the geographical career mobility of working in London as a way of advancing their careers by working in a leading IFC.

Secondments from China in London's financial labour market

The second group of Chinese migrants working in London's financial district are more senior bankers on secondment from mainland China. The financial institutions involved in this process are Chinese state owned commercial banks. Whilst 'individual [Chinese] banks vary on their approach to staffing' (Vice president, Chinese state-owned bank, London February 2015), senior positions within these banks are typically filled through secondments from the Chinese head office with banks 'not using the tier two visa for their own staff' (Head of China Desk, investment bank, London, April 2015). These individuals perform the role of 'diplomat managers' seeking to secure personal career advancement through leading the implementation of regulations and expectations from Beijing, rather than focusing on market making in London. As one Chinese national banker in a Chinese state owned bank observed in June 2015 "I was head of the China desk and there were eight of us in a meeting and all of us were Chinese and none of us were recruited externally". A secondment typically lasts five years and this sets the time horizon within which these managers make decisions. As a result, a risk averse approach to business development predominates over stimulating market demand 
and establishing Chinese banks as legitimate service providers within London. This is because the incentive structure for these individuals prioritises work on the strategic internationalisation of Chinese banks, rather than developing links between these institutions and their international counterparts in London. Comments such as the following were typical amongst the Chinese bankers I interviewed:

"Managers are here for around five years and that means they essentially act as diplomats rather than businessmen [sic]. They are more focussed on not messing up and making mistakes rather than the longer-term strategy of bank internationalisation."

(Trader Chinese bank, Chinese bank, London, February 2015)

Recent work on the internationalisation of transnational service firms has increasingly demonstrated that corporate internationalisation relies not only on responding to client demand in new geographical markets, or following existing clients about new markets but instead focuses on stimulating demand by educating potential new customers into the value of using their services through a range of activities (see Suddaby and Viale, 2011). The reliance on expatriation within these banks in London, and the limited ability to make markets through stimulating client demand associated with this, limits the ability of Chinese banks to grow their client and product base beyond its extant focus on supporting Chinese small and medium 
sized enterprises operating in London (City of London, 2015). As one financial journalist summarised in London in February 2015:

"Chinese banks should be able to create more products to get more clients. They need to face up to becoming a local bank, it is survival. It is a no brainer even to think about your [a Chinese bank] localisation strategy. So, the end of internationalization is localisation, how to become a local bank."

The limited ability of Chinese banks to make markets in this way is significant not only in terms of the career biographies of bankers working within them, but also in terms of the wider position of London within RMB internationalisation, revealing the on-going challenges of sustaining and developing London as an offshore RMB centre, as the following example demonstrates:

"I think that has put them [Chinese banks] in a vulnerable position when they are here in an international market. ... I'm feeling there is a gap between what the British Government wants them to do and what the Chinese banks can do in the market."

(Capital markets lawyer, UK national, London March 2015) 
This form of expatriation therefore differs in important ways from more well studied forms of expatriation out of Europe and North America. The rationale is driven not by a desire to either create new market demand or to spread corporate best practice into a new geographical market (on which see Faulconbridge et al, 2009) but rather is closely entwined with political aspirations in Beijing aimed at developing London as a key node in the emerging RMB internationalisation network of IFCs (see also Hall, 2017a). Taken together, these different forms of elite migration show how elite mobility combines economic and political imperatives such that individual mobility patterns and practices are shot through with macro scale political and economic concerns. This finding is important because it offers a sympathetic critique of the existing literature on elite migration that typically emphasises the economic and personal motivations and experiences mobility, with less attention paid to the political dimensions.

\section{Conclusions}

In this paper, I have used the case of elite Chinese financial migration and expatriation to London's financial district to argue that comparatively neglected forms of elite financial mobility from beyond the Global North provide important insights into the changing geographical form and labour market practices within leading international financial centres. The main empirical contribution of the paper is to provide one of the first analyses to specify the nature of elite Chinese financial 
migration to London and locate this within calls to better understand the marked recent changes in Chinese migration to London more generally (Knowles 2017). This is important because research has typically focused on lower skilled Chinese migration to London. As a result, the implications of the significant numbers of Chinese students studying at UK universities who are seeking graduate level employment in sectors such as finance and related professional services for elite labour markets and economic development within London (as revealed in this paper) and the rest of the UK remain poorly understood.

Whilst these findings have been developed through the unique case of elite Chinese migration into London, this research also contributes to wider agendas concerned with decentring understandings of the global economy (Robinson 2005) by examining flows of elite mobility from rapidly developing economies beyond the Global North. In terms of elite labour market mobility, two implications are important. First, in common with earlier rounds of elite migration, Chinese migration is shaping London's urban form in important ways, not always following previous rounds of urban development stemming from internationalization in London's financial district. Here I support calls to more fully explore the intersection between mobility and cities, particularly in the case of Chinese mobility as this is playing an important but comparatively overlooked role in the ongoing economic development of London (Knowles, 2017). Second, elite Chinese financial migration to London challenges assumptions about the nature of migrants themselves, particularly in terms of their career stage and the rationales behind their mobility with personal 
career aspirations and political agendas from Beijing playing a more important role than organizational strategy which often dominates in existing understandings of elite migration and expatriation. Building on these findings is an important emerging research agenda for social scientists concerned with urban economies and their labour markets, particularly as migration becomes the subject of significant popular and political debate in many parts of the world economy, not least, the UK.

\section{Acknowledgements}

An earlier version of this paper was presented at the Networks in Finance Workshop at Manchester Business School in December 2016. I would like to thank the audience at that event and Adam Leaver and Daniel Tischer for their invitation and engagement with my work. I would also like to thank Elaine Watts who prepared the maps, the individuals who gave up their time to be interviews as part of the wider research project and the comments from four anonymous reviewers that have improved this version of the paper. Any remaining errors remain mine.

\section{References}

Astbury Marsden (2014) City of London lures Chinese speakers to handle surge of work Financial Times 24 March 2014, http://www.ft.com/cms/s/0/9951744ab10b-11e3-bbd4-00144feab7de.htm|\#axzz4EIBjUuN2, accessed 22 July 2016. 
Atkinson, Rowland, Parker, Simon and Burrows, Roger. (2017) Elite formation, power and space in contemporary London Theory, culture and society DOI: $10.1177 / 0263276417717792$

Augar, Philip. (2001). The Death of gentlemanly capitalism. London: Penguin.

Bassens, David, Derudder, Ben, \& Witlox, Frank. (2010). Searching for the Mecca of finance: Islamic financial services and the world city network. Area, 42(1), 3546.

Bassens, David, Derudder, Ben, \& Witlox, Frank (2011). Setting Shari'a standards: On the role, power and spatialities of interlocking Shari'a boards in Islamic financial services. Geoforum, 42(1), 94-103.

Beaverstock, Jonathan (1996). Migration, knowledge and social interaction: Expatriate labour within investment banks. Area, 33, 525-538

Beaverstock, Jonathan (2002). Transnational elites in global cities: British expatriates in Singapore's financial district. Geoforum, 33, 525-538.

Beaverstock, Jonathan (2004). 'Managing across borders': knowledge management and expatriation in professional service legal firms'. Journal of Economic Geography, 4, 157-179. 
Beaverstock, Jonathan (2005). Transnational elites in the city: British highly skilled migrants in New York City's financial district. Journal of Ethnic and Migration Studies, 31, 245-268.

Beaverstock, Jonathan \& Hall, Sarah (2012). Competing for talent: global mobility, immigration and the City of London's labour market. Cambridge Journal of Regions, Economy and Society, 5(2), 271-288.

Bohm, Anthony, Fallari, Marcelo, Hewett, Andrew, Jones, Sarah, Kemp, Neil, Meares, Denis, Pearce, David, Van Cauter, Kevin. (2004). Vision 2020: Forecasting International Student Mobility a UK Perspective. British Council/IDP Australia: London.

British Bankers Association (2015) Diversity and inclusion in Banking, British Bankers Association, London.

Brooks, Rachel. and Waters, Johanna. (2011) Student mobilities, migration and the internationalization of higher education Palgrave MacMillan.

City of London (2015) London RMB business volumes 2014 City of London, Bourse Consult.

Cohen, Benjamin (2012). The yuan tomorrow? Evaluating China's currency internationalisation strategy. New Political Economy, 17, 361-371.

Daniels, Peter. and Bobe, J. M. (1993) Office building in the City of London: a decade of change Area 24, 3, 253-258. 
Dominiczak, Peter. (2013) Most immigrants to the UK now come from China, figures show, The Daily Telegraph, 28 November 2013, available from http://www.telegraph.co.uk/news/uknews/immigration/10480785/Mostimmigrants-to-the-UK-now-come-from-China-figures-show.html, last accessed 15/7/16.

England, Kim, (1994) Getting personal: reflexivity, positionality and feminist research The Professional Geographer 4680 - 89.

Faulconbridge, James, Beaverstock, Jonathan, Hall, Sarah and Hewitson, Andrew. (2009) The war for global talent, Geoforum 40, 800-8.

Findlay, Allan. and Gould, W. T. S. (1989) Skilled international migration: a research agenda Area 21, 1, 3-11.

Findlay, Allan, Li, F Lin, Jowett, A John, Skeldon, Ronald. (1996). Skilled international migration and the global city: a study of expatriates in Hong Kong. Transactions of the Institute of British Geographers 21, 49-61.

Findlay, Allan and Cranston, Sophie (2015) What's in a research agenda? An evaluation of research developments in the arena of skilled international migration, IDPR 37, 1

Florida, Richard (2007) The Flight of the Creative Class New York, Harper Collins

Fortado, Lindsay (2015) Chinese-owned law firm seeks deals in west with London launch Financial Times 31 May 2015, available from https://www.ft.com/content/e05e603e-077f-11e5-a58f-00144feabdc0, last 
accessed 23 August 2017

Hall, Sarah, (2017a) Rethinking international financial centres through the politics of territory: renminbi internationalisation in London's financial district Transactions of the Institute of British Geographers, 42(4), 489-502

Hall, Sarah. (2017b) Regulating the geographies of market making: offshore renminbi markets in London's international financial district Economic Geography http://dx.doi.org/10.1080/00130095.2017.1304806.

Hall, Ssarah. (2017c) Global Finance: people, space and places Sage London.

Higher Education Statistics Agency (HESA)(2017) Higher education student enrolments and qualifications obtained at higher education providers in the United Kingdom 2015/16 available from https://www.hesa.ac.uk/news/12-012017/sfr242-student-enrolments-and-qualifications, (accessed 24 August 2017).

Iredale, Robyn. (2001) The migration of professionals: theories and typologies International Migration 39, 5, 7-26.

JLL (2015) Jones Lang LaSalle London Luxury Quarter available from http://www.jll.co.uk/united-kingdom/en-gb/research/283/london-luxuryquarter-global-destination-appeal, last accessed 18 August 2017.

Johanson, Jan, \& Vahlne, Jan-Erik (2009). The Uppsala internationalization process model revisited: From liability of foreignness to liability of outsidership. Journal of International Business Studies, 40(9), 1411-1431. 
Jones, Andrew. (1998) (Re)producing gender cultures: theorizing gender in investment banking recruitment, Geoforum 29, 4, 451-474.

Kleibert, Jana, \& Kippers, Lisa (2016). Living the good life? The rise of urban mixeduse enclaves in Metro Manila. Urban Geography, 37(3), 373-395.

Knowles, Caroline (2015) Who are the new Chinese migrants in the UK The Runnymede Trust, available from http://www.runnymedetrust.org/blog/whoare-the-new-chinese-migrants-in-the-uk, accessed 22 July 2016.

Knowles, Caroline (2017). Reframing sociologies of ethnicity and migration in encounters with Chinese London. The British Journal of Sociology. doi:10.1111/1468-4446.12271

Koser, Khalid and Salt, John (1997) The geography of highly skilled international migration Population, space and place 3, 4, 285-303

Krijnen, Marieke, Bassens, David \& van Meeteren, Michiel (2017). Manning circuits of value: Lebanese professionals and expatriate world-city formation in Beirut. Environment and Planning A 49, 12, 2878-2896

Kunz, Sarah (2016) Privileged mobilities: locating the expatriate in migration scholarship Geography Compass, 10(3), 89-101

Lai, Karen (2012). Differentiated Markets: Shanghai, Beijing and Hong Kong in China's Financial Centre Network. Urban Studies, 49(6), 1275-1296.

Ley, David (2010) Millionaire Migrants Oxford, Blackwell-Wiley. 
McDowell, Linda (1992). Valid games? A response to Erica Schoenberger. The Professional Geographer, 44(2), 212-215.

McDowell, Linda (1998) Elites in the City of London: some methodological considerations Environment and Planning A 30, 12, 2133-2146.

Moore Fiona 2016 City of sejourners versus city of settles: transnationalism, location and identity among Taiwanese professionals in London and Toronto Global Networks 16, 3, 372-390.

Ong, Aihwa (1999). Flexible Citizenship: The Cultural Logics of Transnationality. Duke University Press: Durham and London.

O'Neill, Philip (2008) Bringing the Qualitative state back into Economic geography in Barnes, T. J., Peck, J.,Sheppard, E. and Tickell, A. (eds) Reading Economic Geography London Wiley

Pieke, Frank (2007). Editorial Introduction : Community and identity in the new Chinese migration order, Population, space and place 94 81-94.

Pratt, Geraldine (1993) Reflections on poststructuralism and feminist empirics, theory and practice, Antipode 25, 1, 51-63.

Pryke, Michael (1991). An international city going global: spatial change in the City of London. Environment and Planning D, 9, 197-222.

Robinson, Jennifer (2005). Urban geography: world cities, or a world of cities. Progress in Human Geography, 6, 757-765. 
Robinson, Jennifer (2002). Global and world cities: a view from off the map. International Journal of Urban and Regional Research, 26(3), 531-554.

Ryan, Louise \& Mulholland, Jon (2014). French connections: the networking strategies of French highly skilled migrants in London. Global Networks, 14(2), $148-166$

Sassen, Saskia (2000) Cities in a World Economy London

Savage, Mike and Williams, Karel 2008 Remembering Elites Blackwell.

Saxenian, AnnaLee (2006) The new Argonauts: regional advantage in a global economy Harvard, Harvard University Press.

Schoenberger, Erica (1991). The corporate interview as a research method in economic geography. The Professional Geographer, 43(2), 180-189.

Schoenberger, Eriva (1992). Self-Criticism and self-awareness in research: A reply to Linda McDowell. The Professional Geographer, 44(2), 215-218.

Sklair, Leslie (2001). The transnational capitalist class. Oxford: Blackwell.

Smith, Michael Peter (2001) Transnational Urbanism: locating globalization Wiley Blackwell

Suddaby, Roy, \& Viale, Thierry. (2011). Professionals and field-level change: Institutional work and the professional project. Current Sociology, 59(4), 423442. 
Thrift, Nigel (1994) 'On the social and cultural determinants of international financial centres: the case of the City of London' In S. Corbridge, R. Martin, N. Thrift (eds), Money, power and space, Blackwell, Oxford 327-354

Thrift, Nigel and Leyshon, Andrew (1992) In the wake of money: the City of London and the accumulation of value In Budd L and Whimster S (eds) Global finance and urban living: a study of metropolitan change Routledge.

The Banker (2014) The banker top 1000 world banks 2014 rankings, 30 June, http://www.thebanker.com/Top-1000-World-Banks/The-Banker-Top-1000World-Banks-2014-rankings-WORLD-Press-release-For-immediate-release, accessed 22 July 2015.

The Financial Times (2016) UK will protect free movement for bankers after Brexit, 19 October, https://www.ft.com/content/eb27252d-94d8-328f-a0e376b890601484, accessed 19 February 2018

Töpfer, Laura-Marie and Hall, Sarah 2017 London's rise as an offshore RMB centre: state-finance relations and selective institutional adaptation Regional Studies, https://doi.org/10.1080/00343404.2016.1275538, accessed 28 March 2018

Tomba Luigi. 2004. Creating an urban middle class: social engineering in Beijing. The China Journal 51: 1-26.

Waters, Johanna (2005). Transnational family strategies and education in the contemporary Chinese diaspora. Global Networks, 5(4), 359-377. 
Waters, Johanna (2006). Geographies of cultural capital: education, international migration and family strategies between Hong Kong and Canada. Transactions, Institute of British Geography, 31, 179-192.

Wildau, Gabriel and Mitchell, Tom (2016) Renminbi Stalls on road to being a global currency, Financial Times 11 December 2016, available from https://www.ft.com/content/e480fd92-bc6a-11e6-8b45-b8b81dd5d080, accessed 24 August 2017.

Xiang, Biao (2003) Emigration from China: a sending country perspective. International Migration 41, 3, 21-48.

Ying, He (2013) China's banks in London, Centre for the Study of Financial Innovation, available from http://csfi.org/files/ chinabanklondonfinal.pdf), last accessed 29 September 2016

Z/Yen (2016) The Global Financial Centres Index 19 Z/Yen, Long Finance. 
Table 1 Educational and career history of research participants (some details have been redacted to ensure the anonymity of individuals. Source: author's research)

\begin{tabular}{|c|c|c|}
\hline Job title & Educational background & Current employer \\
\hline \multirow[t]{2}{*}{ Associate } & Undergraduate degree, China & European investment bank \\
\hline & Postgraduate degree, UK & \\
\hline Trader & Undergraduate degree China & Chinese bank \\
\hline Associate & $\begin{array}{l}\text { Undergraduate degree China, } \\
\text { post graduate degree UK }\end{array}$ & European investment bank \\
\hline Associate & Undergraduate degree UK & European asset management firm \\
\hline Analyst & $\begin{array}{l}\text { Undergraduate degree China, } \\
\text { postgraduate degree UK }\end{array}$ & European investment bank \\
\hline Analyst & $\begin{array}{l}\text { Undergraduate degree China, } \\
\text { postgraduate degree UK }\end{array}$ & UK bank \\
\hline Analyst & $\begin{array}{l}\text { Under and post graduate degrees } \\
\text { in China }\end{array}$ & Chinese bank \\
\hline Analyst & $\begin{array}{l}\text { Undergraduate degree China, } \\
\text { postgraduate degree UK }\end{array}$ & UK bank \\
\hline Analyst & Undergraduate degree China & International finance organisation \\
\hline Analyst & $\begin{array}{l}\text { Undergraduate and postgraduate } \\
\text { degrees in China }\end{array}$ & International finance organisation \\
\hline Analyst & Undergraduate degree China & European investment bank \\
\hline Analyst & Undergraduate degree China & European investment bank \\
\hline Analyst & Undergraduate degree China & Chinese bank \\
\hline Analyst & $\begin{array}{l}\text { Undergraduate and post graduate } \\
\text { degree }\end{array}$ & Chinese bank \\
\hline Analyst & Undergraduate degree China & Chinese bank \\
\hline Associate & $\begin{array}{l}\text { Undergraduate degree Hong } \\
\text { Kong }\end{array}$ & UK bank \\
\hline Associate & $\begin{array}{l}\text { Under and post graduate degrees } \\
\text { UK }\end{array}$ & UK bank \\
\hline Associate & $\begin{array}{l}\text { Undergraduate degree China, } \\
\text { post graduate degree UK }\end{array}$ & UK bank \\
\hline Analyst & Undergraduate degree China & UK bank \\
\hline Analyst & Undergraduate degree UK & European investment bank \\
\hline Associate & Undergraduate degree UK & European investment bank \\
\hline Associate & Undergraduate degree China & $\begin{array}{l}\text { Organisation to support Chinese } \\
\text { finance professionals in London }\end{array}$ \\
\hline Associate & Undergraduate degree UK & $\begin{array}{l}\text { Organisation to support Chinese } \\
\text { finance in London }\end{array}$ \\
\hline Analyst & Undergraduate degree China & Chinese bank \\
\hline Associate & $\begin{array}{l}\text { Under and post graduate degrees } \\
\text { in the UK }\end{array}$ & European investment bank \\
\hline Analyst & $\begin{array}{l}\text { Undergraduate degree China, } \\
\text { postgraduate degree UK }\end{array}$ & Boutique investment firm \\
\hline Associate & $\begin{array}{l}\text { Undergraduate degree China, } \\
\text { postgraduate degree UK }\end{array}$ & Boutique investment firm \\
\hline $\begin{array}{l}\text { Corporate } \\
\text { lawyer }\end{array}$ & $\begin{array}{l}\text { Undergraduate degree China, } \\
\text { postgraduate degree UK }\end{array}$ & International law firm \\
\hline
\end{tabular}




$\begin{array}{lll}\begin{array}{l}\text { Corporate } \\ \text { lawyer, China }\end{array} & \text { Undergraduate degree Hong } & \text { International law firm } \\ \text { specialist } & \text { Kong, postgraduate degree UK } & \\ \begin{array}{l}\text { Capital markets } \\ \text { lawyer }\end{array} & \text { Undergraduate degree UK } & \text { International law firm } \\ & & \end{array}$
lawyer 


\section{Figure 1}

\% increase in annual National Insurance registrations for Chinese nationals by London Borough, 2002/3 - 2015/16.

Source: Department for work and pensions

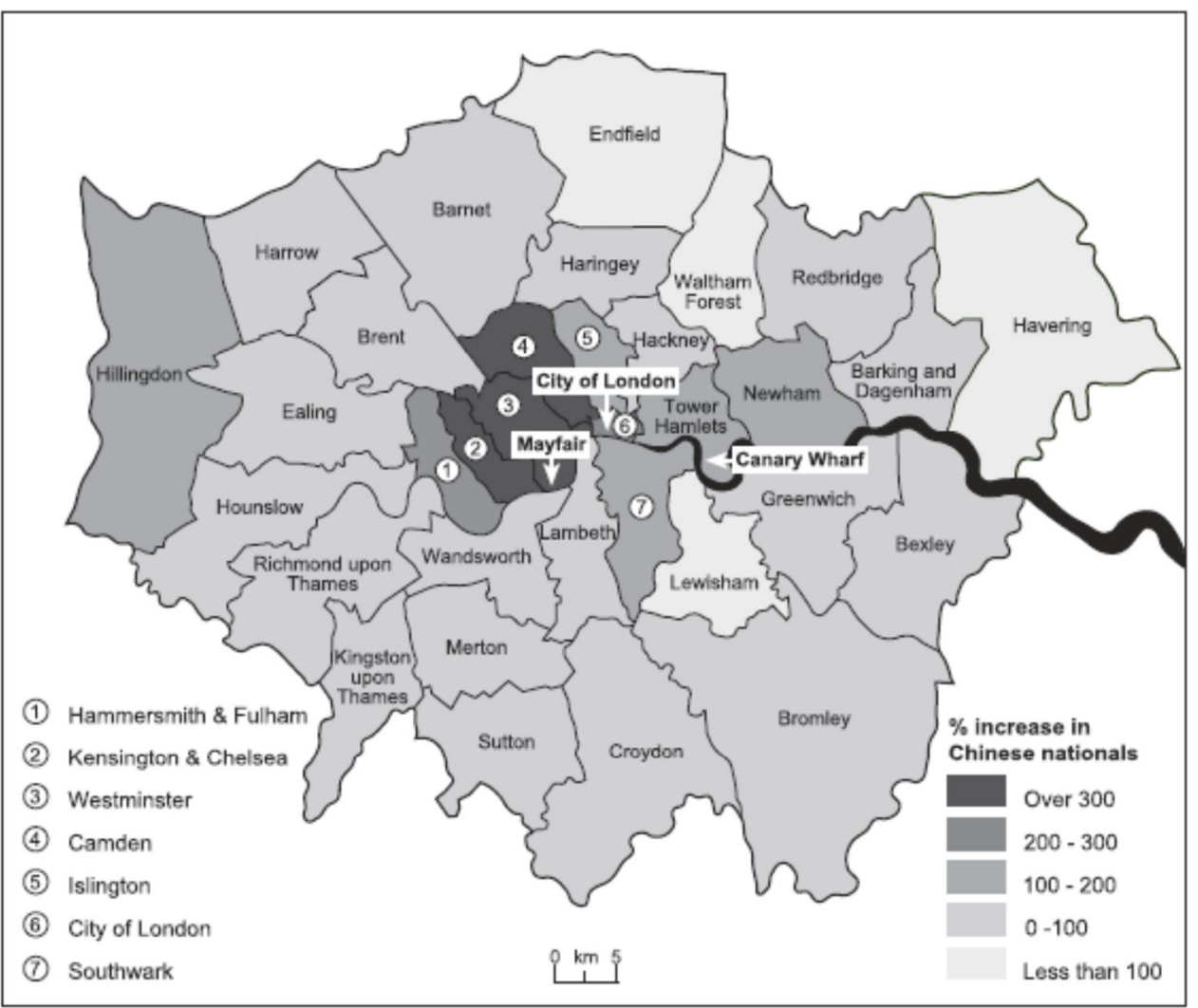


Figure 2 Location of main Chinese financial institutions operating in London

Source: Author's research

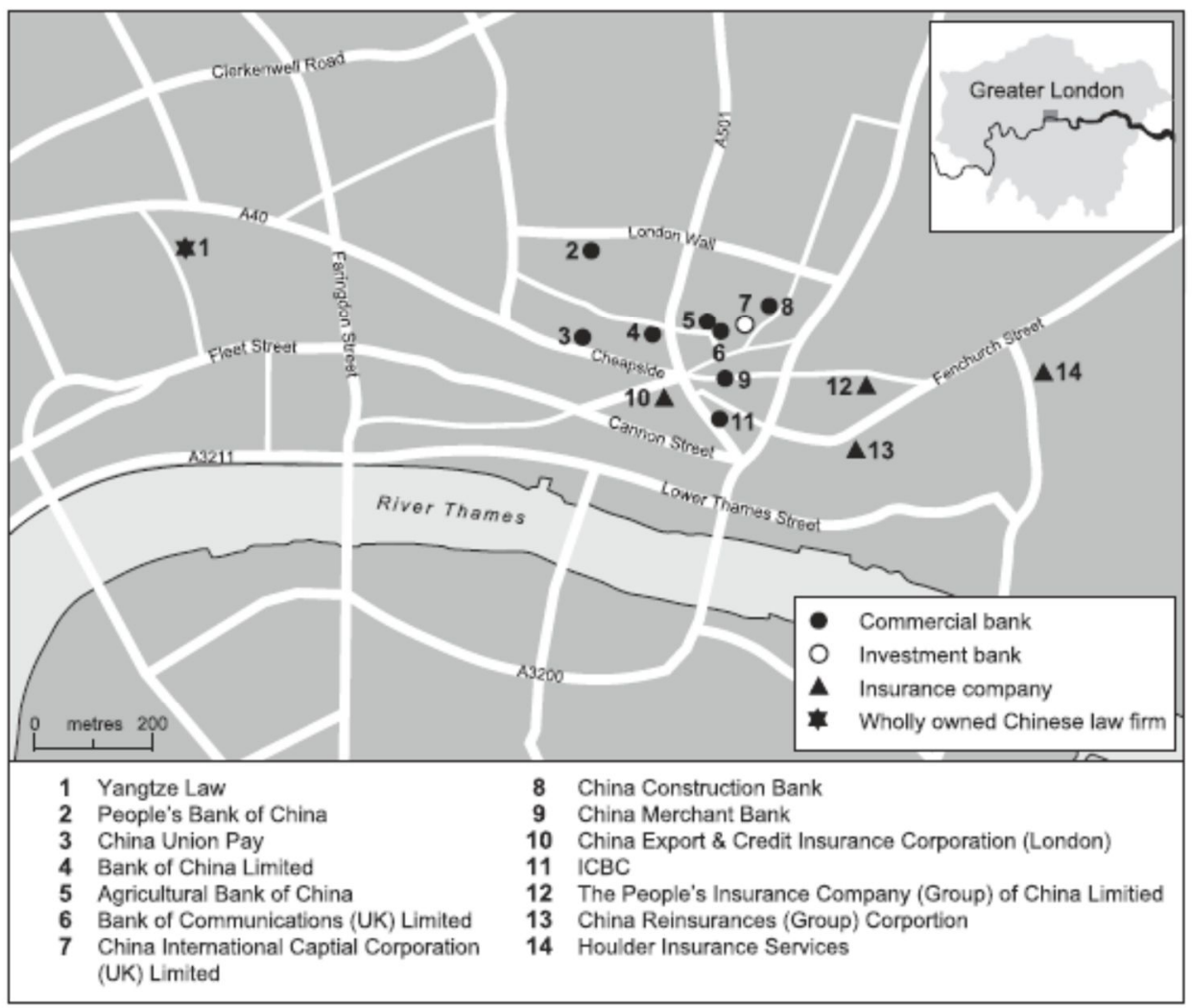


Table 2: Big four Chinese commercial state owned banks operating in London, by tier 1 capital

\begin{tabular}{|c|c|c|c|c|c|c|}
\hline Bank & $\begin{array}{l}\text { Date of } \\
\text { foundin } \\
g \text { in } \\
\text { China }\end{array}$ & $\begin{array}{l}\text { Headquart } \\
\text { er location }\end{array}$ & $\begin{array}{l}\text { Tier } 1 \\
\text { capital } \\
\$ m\end{array}$ & $\begin{array}{l}\text { World } \\
\text { Ranking } \\
\text { by tier } 1 \\
\text { capital } \\
\text { (previou } \\
\text { S } \\
\text { ranking) }\end{array}$ & $\begin{array}{l}\text { Summary } \\
\text { of } \\
\text { internation } \\
\text { al presence }\end{array}$ & $\begin{array}{l}\text { Date } \\
\text { granted } \\
\text { UK bank } \\
\text { branch } \\
\text { license }\end{array}$ \\
\hline $\begin{array}{l}\text { Industrial } \\
\text { and }\end{array}$ & 1984 & Beijing & $\begin{array}{l}207,61 \\
4\end{array}$ & $1(1)$ & $\begin{array}{l}400 \text { overseas } \\
\text { branches in } \\
39 \text { countries }\end{array}$ & $\begin{array}{l}\text { Septemb } \\
\text { er } 2014\end{array}$ \\
\hline Commercia & & & & & & \\
\hline I Bank of & & & & & & \\
\hline China & & & & & & \\
\hline $\begin{array}{l}\text { China } \\
\text { Constructio } \\
\text { n Bank }\end{array}$ & 1954 & Beijing & $\begin{array}{l}173,99 \\
2\end{array}$ & $2(5)$ & $\begin{array}{l}76 \text { overseas } \\
\text { branches in } \\
\text { Germany, } \\
\text { Luxembourg, } \\
\text { Vietnam, } \\
\text { Sought Africa, } \\
\text { Australia, US, } \\
\text { South Korea, } \\
\text { Singapore, } \\
\text { Japan }\end{array}$ & $\begin{array}{l}\text { January } \\
2015\end{array}$ \\
\hline $\begin{array}{l}\text { Bank of } \\
\text { China }\end{array}$ & 1912 & Beijing & $\begin{array}{l}149,72 \\
9\end{array}$ & $7(9)$ & $\begin{array}{l}100 \text { branches } \\
\text { in } 36 \\
\text { countries }\end{array}$ & 2015 \\
\hline $\begin{array}{l}\text { Agricultura } \\
\text { I Bank of } \\
\text { China }\end{array}$ & 1951 & Beijing & $\begin{array}{l}137,41 \\
0\end{array}$ & $9(10$ & $\begin{array}{l}\text { Branches in } \\
\text { Hong Kong, } \\
\text { London, } \\
\text { Tokyo, New } \\
\text { York, } \\
\text { Frankfurt, } \\
\text { Sydney, Seoul } \\
\text { and Singapore }\end{array}$ & 2015 \\
\hline
\end{tabular}

Sources: The Banker, 2014 and bank annual reports 